\title{
Model Project-Based Learning Berbantuan Penilain Teman Sebaya di Tengah Pandemi untuk Meningatkan Hasil Pendidikan IPS Mahasiswa PGSD
}

\author{
I Kadek Edi Yudiana ${ }^{1}$, Ni Wayan Eka Widiastini ${ }^{2}$, L Heny Nirmayani ${ }^{3}$
}

1,2,3 Pendidikan Guru Sekolah Dasar, Universitas Pendidikan Ganesha, Singaraja, Indonesia

\section{ART ICLE INFO}

Article history:

Received July 19, 2021

Revised July 23, 2021

Accepted October 26, 2021

Available online December 25, 2021

Kata Kunci:

Project-Based Learning, Penilain

Teman Sebaya

Keywords:

Project-Based Learning,Peer Rating

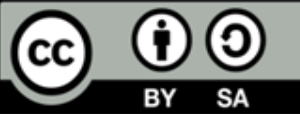

This is an open access article under the CC BY-SA license.

Copyright $(2021$ by Author. Published by Universitas Pendidikan Ganesho.

\begin{abstract}
A B S T R A K
Pembelajaran daring tidak selamanya baik banyak masih kekurangannya salah satunya adalah mahasiswa merasa bosan karena proses pembelajaran monoton dan kurang menarik. Sehingga mahasiswa tidak tertarik belajar dan menyelesaikan pembelajaran yang dilakukan di di e-learning. Penelitian ini bertujuan untuk mengkaji pengaruh model model Project-Based Learning (PjBL) berbatuan penelian teman sebaya terhadap hasil belajar. Jenis penelitian yang dilakukan adalah penelitian semu. Rancangan penelitian ini menggunakan rancangan posttest only control group design Populasi penelitian ini adalah seluruh mahasiswa semester II PGSD yang ada di Singaraja yang berjumlah 170 mahasiswa yang tersebar secara merata di 6 kelas yaitu kelas A-F. Data diperoleh dari hasil perhitungan skor tes hasil belajar mahasiswa. Penelitian ini menggunakan dua teknik analisis yaitu analisis deskriptif dan analisis inferensial. Hasil analisis dengan uji $\mathrm{t}$ diperoleh terdapat perbedaan antara mahasiswa yang belajar dengan model Project-Based Learning berbatuan penelian teman sebaya dengan mahasiswa yang belajar dengan daring. Hal ini dapat dilihat dari nilai sig. yang lebih kecil dari 0,05 yaitu 0,00. Jadi, model Project-Based Learning berbantuan penilaian teman sebaya memberikan pengaruh yang positif terhadap hasil belajar. Sehingga di rekomdasikan sebagai salah satu model pembelajaran yang digunakan dalam pembelajaran daring.
\end{abstract}

\section{A BS TRACT}

Online learning is not always good many still lack one of them is students feel bored because the learning process is monotonous and less interesting. So that students are not interested in learning and completing learning that is done in e learning. This study aims to examine the influence of the rocky PjBL model of peer-neutrality on learning outcomes. The type of research done is pseudoresearch. This research design uses the posttest only control group design design This study population is all pgsd semester ii students in Singaraja which amounted to 170 students spread evenly across 6 classes, namely class A - F. Data obtained from the results of the calculation of student learning test scores. This study uses two analytical techniques: descriptive analysis and inferential analysis. The results of the analysis with the t test found there was a difference between students who studied in a rocky PjBL model with peers and students who studied online. This can be seen from the sig value. Smaller than 0.05 is 0.00 . So, the existence of a PjBL learning model assisted by peer assessments has a positive influence on learning outcomes. So that it is recomped as one of the learning models used in online learning.

\section{PENDAHULUAN}

Pendidikan IPS adalah disiplin-displin ilmu sosial ataupun integrasi dari berbagai cabang ilmu sosial seperti: sosiologi, sejarah, geografi, ekonomi, dan antropologi yang mempelajari masalah-masalah social (Donas Ahmad Najib \& Elhefni, 2016). Pendidikan IPS yang baik adalah pembelajaran dengan mengkaitkan dan memadukan dari berbagai materi ilmu-ilmu sosial dalam konteks yang mengikuti perkembangan zaman dan disesuaiakan dengan pengajaran (Nilasari, 2013). Pembelajaran IPS 
mengandung nilai-nilai kearifan yang dapat digunakan dalam pembentukan sikap, watak, dan kepribadian siswa. Pembelajaran IPS memiliki tujuan yang sangat strategis kaitannya dengan pembentukan dan pembangunan negara yang berkualitas untuk membekali siswa seperangkat pengetahuan, sikap, nilai, moral, dan keterampilan sosial agar dapat memahami dan melakoni lingkungan masyarakat sekitar, serta sebagai dasar untuk melanjutkan pendidikan ke jenjang yang lebih tinggi (Andi et al., 2017). Pentingnya pembelajaran IPS diberikan, tentunya menjadi tantangan tersendiri bagi pengajar untuk menciptakan pembelajaran yang menyenangkan dan tentunya menarik bagi peserta.

Pembelajaran yang baik adalah pembelajaran yang memberikan kesempatan kepada mahasiswa untuk belajar mandiri dan membangun pengetahuannya sendiri. saat ini metode pembelajaran yang digunkan adalah pembelajaran daring dimana mahasiswa belajar dengan bantuan Internet. Pembelajaran daring/online merupakan suatu kegiatan belajar yang membutuhkan jaringan internet dengan konektivitas, aksesibilitas, fleksibilitas, serta kemampuan untuk memunculkan berbagai jenis interaksi pembelajaran (Oktafia \& Wulandari, 2020). Pembelajaran daring adalah pembelajaran yang dilakukan dengan bantuan internet, yang memberikan kesempatan kepada siswa untuk belajar lebih mandiri tanpa adanya batas ruang dan waktu (O’Doherty et al., 2018). Dengan adanya pembelajaran daring memberikan kesepatan peserta didik untuk bertukar pendapat dengan orang lain dan memberikan kesempatan kepada peserta didik untuk belajar mandiri (Hwang et al., 2020). Alat bantu yang bisa digunakan dalam proses pembelajaran daring adalah google meet, google room, google classroom, WA, dan social media (Chang et al., 2020).

Namun, tidak selamanya pembelajaran online/daring tersebut berdampak positif, pembelajaran daring berdampak terhadap perubahan sikap isolasi social, kurangnya interaktivitas, partisiapsi dan keterbatasan umpan balik. Kurang siapnya orang tua dalam menghadapi pembelajaran online, pembelajaran online tidak mempunyai suasan formal seperti pembelajaran tradisional, pada pembelajaran online tidak terjadi interaksi social sesama peserta didik (Dong et al., 2020). Banyak anak yang tidak melakukan pembelajaran online, melakukan aktivitas yang youtube serta kegiatan yang lain yang menunjukkan adanya kecanduan "gawe"(Liu et al., 2020; Rahmawati \& Latifah, 2020; Samaha \& Hawi, 2016). Serta masalah yang lain adalah dengan pemberian masalah yang terlalu rumit akan menyebakan peserta didik frustasi dan tidak ingin belajar. Dengan kondisi ini akan sangat mempengaruhi hasil belajar yang nantinya akan berdapak terhadp kualitas output Pendidikan. Begitu juga halnya yang terjadi pada mahasiswa PGSD, minat belajar daring mereka sangat rendah, jarang skali mereka mau buka kamera saat meet maupun zoom dalam proses perkuliahan. Interaksi antar mahasiswa juga sangat rendah sekali. Pengerjaan tugas di E-Learning hanya sekedar isi saja dan sepertinya tidak ada keseriusan mereka mengerjakan tugas secara on-line sehingga nilai mereka menjadi rendah.

Mengatasi masalah tersebut dibutuhkan sebuah model pembelajaran yang bisa membuat mahasiswa belajar dengan aktif dan belajar dengan perasaan yang nyaman. Salah satu modela pembelajaran yang bisa digunakan adalah model Project-Based Learning (PjBL). Pembelajaran berbasis proyek berkaitan dengan dunia nyata siswa yang memerlukan penyelidikan kolaboratif dan produksi serta serangkaian proyek (Muhammad, 2018). Pembelajaran berbasis proyek merupakan pembelajaran yang inovatif yang menekankan pada kegiatan kompleks dengan tujuan pemecahan masalah dengan berdasar pada kegiatan inkuri (Kurniawan et al., 2018). Pembelajaran dengan PjBL, guru bertanggung jawab melakukan monitor terhadap aktivitas siswa selama menyelesaikan proyek, sehingga siswa mampu mengembangkan suatu gagasan dan menghasilkan hasil yang memuaskan (Muhammad, 2018; Rahmazatullaili et al., 2017). Fokus pembelajaran terletak pada konsep-konsep dan prinsip-prinsip inti dari suatu disiplin studi, melibatkan pebelajar dalam investigasi pemecahan masalah dan kegiatan tugastugas bermakna yang lain, memberi kesempatan pebelajar bekerja secara otonom mengkonstruk pengetahuan mereka sendiri, dan mencapai puncaknya menghasilkan produk nyata (Sumarni, 2020). Jadi, penerapan model PjBL dalam proses pembelajaran memberikan dampak poasitif dalam proses pembelajaran. selain model, untuk membuat suasana pembelajaran lebih menyenangkan bisa dilakukan dengan cara menggunkan penilain teman sebaya.

Penilaian teman sebaya adalah salah satu penilaian yang dilakukan oleh teman sebaya untuk menilai pekerjaan temannya (Alias et al., 2015; Jalili \& Shishavan, 2020). Penilaian teman sebaya digunakan dalam proses penilaian projek atau persentasi. Penilaian teman sebaya penting dalam mengavaluasi dan mendorong terjadinya umpan balik yang baik (Liang et al., 2020; Luaces et al., 2018). Penilaian teman sebaya meningkatkan akuntabilatas dan menginspirasi mereka untuk meningkatkan interaksi dengan teman sebaya sehingga dihasilkan penilaian yang bersifat heterogeny (James et al., 2018). Strategi Penilaian teman sebaya sangat diperlukan dalam proses pembelajaran karena akan mengembangkan interaksi social antara teman sebaya. Kelebihan masing-masing komponen yaitu model dan jenis penilain ini menjadi salah satu alasan mengapa penelitian ini dilakukan. Penelitian ini bertujuan untuk mengkaji pengaruh model PjBL berbatuan penelian teman sebaya terhadap hasil belajar. 
Penerapan model pembelajaran diharapakan dapat mengurangi kebosananan mahasiswa dalam proses pembelajaran serta proses penilaian teman sebaya memberikan kesempatan kepada mahasiswa untuk termotivasi mengikuti pembelajaran.

\section{METODE}

Jenis penelitian yang dilakukan adalah eksperimen semu. Eksperimen semu adalah jenis komparasi yang membandingkan pengaruh pemberian suatu perlakuan (treatment) pada suatu objek (kelompok eksperimen) serta melihat besar pengaruh perlakuannya (Arikunto, 2015). Rancangan penelitian ini menggunakan rancangan posttest only control group design. Populasi penelitian ini adalah seluruh mahasiswa semester II PGSD yang ada di Singaraja yang berjumlah 170 mahasiswa yang tersebar secara merata di 6 kelas yaitu kelas A-F. Sampel penelitian ini adalah mahasiswa semesrter II PGSD. Atau dengan kata lain pengambilan sampel dilakukan dengan tehknik group random sampling. Pengambilan sampel dilakukan dalam dua tahap. Tahap pertama, diundi dua kelas yang ada PGSD Singaraja secara random dan hasilnya sebagai sampel penelitian. Dari kedua kelas, selanjutnya dipilih secara random menjadi 1 kelas eskperimen dan 1 kelas kontrol. Dari hasil tersebut diperoleh kelas A sebagai kelompok eksperimen dengan jumlah 30 orang mahasiswa dan kelas B sebagai kelas control dengan mahasiswa sebanyak 30 orang. Objek penelitian ini adalah hasil belajar mahasiwa pada mata kuliah pendidikan IPS SD yang telah diberikan eksperimen berupa yaitu Project-Based Learning ( $\mathrm{PjBl}$ ) berbantuan penilain teman sebaya dengan variable terikat yaitu hasil belajar mahasiswa. Hasil belajar diukur dengan instrument tes. Tes uraian ini akan terdiri dari soal pilihan ganda dengan tingkat kognitif dari C4-C6. Tes akan diambil dari materi Strategi Pembelajaran IPS SD dan Model, Metode Pembelajaran IPS SD. Tahapantahapan penelitian yang dilakukan dalam penelitian ini, dapat dipaparkan sebagai berikut. 1) Tahap Persiapan, pada tahap ini meliputi: analisis kurikulum, analisis materi, merancang pembelajaran (RPS) Pendidikan IPS, merancang evaluasi (prosedur, instrument, kunci jawaban, pedoman evaluasi). Dan 2) Tahap Pelaksanaan, pada tahap ini meliputi: kegiatan pembelajaran di kelas dengan yaitu Project-Based Learning ( $\mathrm{PjBl}$ ) berbantuan penilain teman sebaya dengan variable terikat yaitu hasil belajar mahasiswa. Tahap Analisis, pada tahap ini meliputi kegiatan evaluasi dan analisis hasil belajar mahasiswa dengan memberikan tes hasil belajar.

Data yang dikumpulkan dalam penelitian ini adalah data skor hasil belajar mahaiswa mahasiswa semester II PGSD yang mengikuti pembelajaran PjBl berbantuan penilain teman sebaya yang diterapkan di kelas eksperimen dan pembelajaran tanpa pembelajaran PjBl berbantuan penilain teman sebaya. Data diperoleh dari hasil perhitungan skor tes hasil belajar mahasiswa. Data yang dikumpulkan ditabulasi rerata dan simpanagan baku menyangkut data hasil belajar. Penelitian ini menggunakan dua teknik analisis yaitu analisis deskriptif dan analisis infrensial. Teknik analisis statistik deskriptif digunakan untuk mendeskripsikan data yang diperoleh. Data yang telah diperoleh dari penelitian dideskripsikan menurut variabel hasil belajar. Analisis deskriptif menampilkan rata-rata, standar deviasi, modus, median, nilai minimum, nilai maksimum, jangkauan, dan jumlah data dari setiap variabel yang diteliti. Analisis infrensial digunakan untuk menguji hipotesis penelitian. Pengujian hipotesis digunkan adalah Uji t digunakan untuk menguji tingkat signifikan dari pengaruh variabel independen secara parsial terhadap variabel dependen. Uji dilaksanakan dengan langkah membandingkan $t$ hitung dengan $t$ tabel. Dengan ketentuan jika $t$ hitung $>t$ tabel dan nilai signifikan $<0,05(\alpha: 5 \%)$, maka variabel independen secara parsial berpengaruh signifikan terhadap variabel dependen. Pengujian hipotesis ini dibantu dengan SPSS 20.

\section{HASIL DAN PEMBAHASAN}

\section{Hasil}

Tujuan penelitian yaitu untuk mengetahui pengaruh pembalajaran PjBl berbantuan penilain teman sebaya di tengah pandemi untuk meningatkan hasil pendidikan IPS mahasiswa PGSD. Dalam penelitian ini ada dua variable yang digunakan yaitu variable bebas yaitu pembalajaran PjBl berbantuan penilain teman sebaya dengan variable terikat yaitu hasil belajar mahasiswa. Hasil analisis data deskritif ditunjukkan pada Tebel 1. Diperoleh bahwa terdapat perbedaan hasil belajar mahasiswa hal ini ditunjukkan dari hasil mean dimana kelas ekperiment mempunyai nilai mean yang lebih besar yaitu 75,1 dengan median 75, standar deviasi 6,8, nilai Maksimum 89 dan nilai minimum 89. Untuk Tingkat katagori kelas eksperimet berada pada katagori sangat baik dan baik yang masing-masing persentasenya $56,7 \%$ dan 43,3\%. Sedangkan untuk kelas kontrol hasil berlajar mahasiswa berada pada katagori baik sebesar 76,7\%. Untuk lebih lengkap ditunjukkan pada Tabel 2. Jadi, berdasarkan hasil penelitian deskriptif 
diperoleh terdapat perbedaan pembalajaran PjBl berbantuan penilain teman sebaya di tengah pandemi untuk meningatkan hasil pendidikan IPS mahasiswa PGSD.

Tabel 1. Hasil analisis deskriptif

\begin{tabular}{ccc}
\hline Komponen yang diukur & Eksperiment & Kontrol \\
\hline Mean & 75,1 & 67 \\
Median & 75 & 65 \\
Standar Deviasi & 6,8 & 6,7 \\
Max. & 89 & 80 \\
Min. & 65 & 55 \\
\hline
\end{tabular}

Tabel 2. Kelas Interval untuk Masing-Masing Kategori

\begin{tabular}{clllll}
\hline Interval Skor & Ekperimen & Persentase & Kontrol & Persentase & \multicolumn{1}{c}{ Kategori } \\
\hline $75,05-100$ & 17 & $56,7 \%$ & 4 & $13,3 \%$ & Sangat Baik \\
$58,35-75,04$ & 13 & $43,3 \%$ & 23 & $76,7 \%$ & Baik \\
$41,65-58,34$ & 0 & $0 \%$ & 5 & $10 \%$ & Cukup \\
$24,95-41,64$ & 0 & $0 \%$ & 0 & $0 \%$ & Kurang \\
$0-24,94$ & 0 & $0 \%$ & 0 & $0 \%$ & Sangat Kurang \\
\hline
\end{tabular}

Setelah dilakukan uji analisis secara seskriptif uji selanutnya yaitu uji infensial dengan Uji t. Namun sebelumnya dilakukan uji prayarat, uji Prayarat yang dilakukan adalah uji Normalitas dengan Kolmogorov-Smirnov, hasil perhitungan diperoleh data hasil penelitian berdistribusi Normal. Dimana nilai Sig. lebih besar dari 0,05. Hasil lebih lengkap ditunjukan pada Tabel 3. Setelah dilakukan uji normalitas dilanjutkan dengan uji homogenitas, berdasarkan hasil analisis dengan Levene's Test diperoleh nilai sig. 0,797 yang mana nilai ini lebih dari 0,05 yang berarti data yang diperoleh berasal dari kelas homogen. Berdasarkan hasil uji prasyarat maka dapat dikatakan bahwa data hasil penelitian bersal dari sebaran data normal dan homogen sehingga uji t bisa dilakukan. Hasil analisis dengan uji t diperoleh terdapat terdapat perbedaan pembalajaran PjBl berbantuan penilain teman sebaya di tengah pandemi untuk meningatkan hasil pendidikan IPS mahasiswa PGSD dengan mahasiswa yang belajar secara daring. Hal ini dapat dilihat dari nilai sig. yang lebih kecil dari 0,05 yaitu 0,00.

Tabel 3. Hasil uji Normalitas

\begin{tabular}{lcrrrrrr}
\hline & \multicolumn{2}{c}{ Kolmogorov-Smirnova } & \multicolumn{3}{c}{ Shapiro-Wilk } \\
\hline & Statistic & df & & Sig. & Statistic & df & Sig. \\
\hline Eksperimnet & 0,142 & 30 & 0,126 & 0,949 & 30 & 0,156 \\
Kontrol & 0,151 & 30 & 0,077 & 0,961 & 30 & 0,516 \\
\hline
\end{tabular}

\section{Pembahasan}

Hasil penelitian menunjukkan terdapat perbedaan pembalajaran PjBl berbantuan penilain teman sebaya di tengah pandemi untuk meningatkan hasil pendidikan IPS mahasiswa PGSD. Kondisi ini tidak terlepas dari model pembelajaran yang digunakan. Dengan adanya model PjBl berbantuan penilaian teman sebaya akan membuat suasana pembelajaran lebih aktif serta terjalinnya interaksi yang baik antar mahasiswa. Adanya interaksi yang baik ini akan membuat hasil belajar siswa meningkat. Hasil belajar yaitu perubahan perilaku dari hasil pengalaman belajar yang terdiri dari 3 ranah; kognitif, afektif dan psikomotor. Hasil belajar adalah suatu perubahan perilaku yang terjadi setelah mengikuti proses belajar mengajar sesuai dengan Berhasil atau tidaknya seseorang tujuan pendidikan (Novianti et al., 2020). Keberhasilan belajar disebabkan beberapa faktor yang mempengaruhi pencapaian hasil belajar yaitu berasal dari dalam diri orang yang belajar (faktor internal) dan ada pula dari luar dirinya(faktor eksternal). Faktor dalam meliputi faktor fisiologi (kondisi fisik dan kondisi panca indera). Faktor psikologi diantaranya bakat, minat, kecerdasan, motivasi, kemampuan kognitif. Sedangkan faktor luar meliputi faktor lingkungan dan factor instrumental. Faktor lingkungan ialah faktor alam dan faktor social (M.Ngalim, 2007). Jadi, keberhasilan proses pembelajaran sangat dipengaruhi oleh model pembelajaran yang digunakan. Hal ini sesaui dengan hasil penelitian ini dimana dengan adanya moel pembelajaran PjBL mahasiswa akan lebih aktif dalam membanguan pengetahuannya sendiri.

Pembelajaran berbasis proyek merupakan pembelajaran yang inovatif yang menekankan pada kegiatan kompleks dengan tujuan pemecahan masalah dengan berdasar pada kegiatan inkuri (Kurniawan 
et al., 2018). PjBL merupakan pembelajaran yang inovatif yang menekankan pada kegiatan kompleks dengan tujuan pemecahan masalah dengan berdasar pada kegiatan inkuri (Apriyanto et al., 2017; Arizona et al., 2020). Pembelajaran dengan PjBL, guru bertanggung jawab melakukan monitor terhadap aktivitas siswa selama menyelesaikan proyek, sehingga siswa mampu mengembangkan suatu gagasan dan menghasilkan hasil yang memuaskan (Rahmazatullaili et al., 2017). Fokus pembelajaran terletak pada konsep-konsep dan prinsip-prinsip inti dari suatu disiplin studi, melibatkan pebelajar dalam investigasi pemecahan masalah dan kegiatan tugas-tugas bermakna yang lain, memberi kesempatan pebelajar bekerja secara otonom mengkonstruk pengetahuan mereka sendiri, dan mencapai puncaknya menghasilkan produk nyata (Sumarni, 2020). Jadi, penerapan model PjBL dalam proses pembelajaran memberikan dampak positif dalam proses pembelajaran. Dalam penelitian ini juga selain model PjBL yang digunakan, proses penilian yang dilakukan adalah teman sebaya. Adanya proses penilaian teman mempengaruhi hasil belajar.

Penilaian teman sebaya adalah salah satu penilaian yang dilakukan oleh teman sebaya untuk menilai pekerjaan temannya (Alias et al., 2015; Jalili \& Shishavan, 2020). Penilaian teman sebaya digunakan dalam proses penilaian projek atau persentasi. Penilaian teman sebaya penting dalam mengavaluasi dan mendorong terjadinya umpan balik yang baik (Liang et al., 2020; Luaces et al., 2018). Penilaian teman sebaya meningkatkan akuntabilatas dan menginspirasi mereka untuk meningkatkan interaksi dengan teman sebaya sehingga dihasilkan penilaian yang bersifat heterogeny (James et al., 2018). Strategi Penilaian teman sebaya sangat diperlukan dalam proses pembelajaran karena akan mengembangkan interaksi social antara teman sebaya. Strategi Penilaian teman sebaya sangat diperlukan dalam proses pembelajaran karena akan mengembangkan interaksi social antara teman sebaya. Pembelajaran yang melibatkan teman sebaya akan mengurangi kecemasan dan setres, dengan dibimbing, dibantu, dan diberikan uampan balik oleh teman sebaya peserta didik akan dapat meningkatkan kepercayaan diri (Han et al., 2015; Stone et al., 2013). Pembelajaran yang melibatkan peserta didik akan menghasilkan pembelajaran yang lebih kondusif.

Jadi, dapat dikatakan bahwa adanya model PjBL berbantuan penilaian teman sebaya memberikan pengaruh yang poasitif terhadap hasil belajar. Hal ini disebakan oleh model ini memberikan kesempatan kepada mahasiswa untuk melakukan pembelajaran secara aktif dalam memecahkan masalah dan memberikan kesempatakan kepada mahasiswa untuk mengaktualisasikan dirinya. Hal ini tentunya sangat berdampak terhadap maotivasi mahasiswa dalam proses pembelajaran. Dengan adanya doroangan untuk belajar dan saling mempengaruhi sesama teman sebanya akan berdampak terhadap peningkatan pengetahuan. Selian kelebihan penelitian ini masih ada kekuranganya dimana proses pembelajaran masih belum menggunakan jumlah sampel yang lebih banyak kerena terbentur dengan adanya Covid-19. Namun, peneliti yakin jika model pembelajaran ini digunakan akan tetap memberikan dampak yang Positif terhadap pembelajaran.

\section{SIMPULAN}

Adanya model PjBL berbantuan penilaian teman sebaya memberikan pengaruh yang positif terhadap hasil belajar. Hal ini disebakan oleh model ini memberikan kesempatan kepada mahasiswa untuk melakukan pembelajaran secara aktif dalam memecahkan masalah dan memberikan kesempatakan kepada mahasiswa untuk mengaktualisasikan dirinya. Sehingga di rekomdasikan sebagai salah satu model pembelajaran yang digunakan dalam pembelajaran daring.

\section{DAFTAR PUSTAKA}

Alias, M., Masek, A., \& Salleh, H. H. M. (2015). Self, Peer and Teacher Assessments in Problem Based Learning: Are They in Agreements? Procedia - Social and Behavioral Sciences, 204(November 2014), 309-317. https://doi.org/10.1016/j.sbspro.2015.08.157.

Andi, I. P., Arsana, B., Jampel, I. N., \& Kusmariyatni, N. (2017). Pengaruh model pembelajaran kooperatif tipe stad ips kelas iv sd universitas pendidikan ganesha. Mimbar pgsd, 5(1). http://dx.doi.org/10.23887/jjpgsd.v5i2.11031.

Apriyanto, B., Nurdin, E. A., Ikhsan, F. A., \& Kurniawan, F. A. (2017). Penerapan Pembelajaran Berbasis Masalah Untuk Meningkatkan Aktivitas Dan Hasil Belajar Siswa Dalam Memahami Lingkungan Hidup Pada Mata Pelajaran Ips Di Smp Negeri 2 Sukodono. Jurnal Pendidikan Ekonomi: Jurnal Ilmiah Ilmu Pendidikan, Ilmu Ekonomi Dan Ilmu Sosial, 11(2), 7. https://doi.org/10.19184/jpe.v11i2.5727.

Arikunto, S. (2015). Dasar-Dasar Evaluasi Pendidikan. Bumi Aksara.

Arizona, K., Abidin, Z., \& Rumansyah, R. (2020). Pembelajaran Online Berbasis Proyek Salah Satu Solusi 
Kegiatan Belajar Mengajar Di Tengah Pandemi Covid-19. Jurnal Ilmiah Profesi Pendidikan, 5(1), 64-70. https://doi.org/10.29303/jipp.v5i1.111.

Chang, T. Y., Hong, G., Paganelli, C., Phantumvanit, P., Chang, W. J., Shieh, Y. S., \& Hsu, M. L. (2020). Innovation of dental education during COVID-19 pandemic. Journal of Dental Sciences, 155. https://doi.org/10.1016/j.jds.2020.07.011.

Donas Ahmad Najib, \& Elhefni. (2016). Pengaruh Penerapan Pembelajaran Bermakna (Meaningfull Learning) Pada Pembelajaran Tematik IPS Terpadu Terhadap Hasil Belajar Siswa Kelas III di MI Ahliyah IV Palembang. JIP: Jurnal Ilmiah PGMI, 2(1), 19-28.

Dong, C., Cao, S., \& Li, H. (2020). Young children's online learning during COVID-19 pandemic: Chinese parents' beliefs and attitudes. Children and Youth Services Review, 118(June), 105440. https://doi.org/10.1016/j.childyouth.2020.105440.

Han, J.-S., Baek, H. C., \& Jeong, A.-S. (2015). The Effects of Psychiatric Nursing Simulation on Anxiety and Self-confidence about Clinical Placement of Nursing Students. Journal of the Korea Academia$\begin{array}{llll}\text { Industrial Cooperation } & \text { Society, }\end{array}$ https://doi.org/10.5762/kais.2015.16.11.7812.

Hwang, G. J., Wang, S. Y., \& Lai, C. L. (2020). Effects of a social regulation-based online learning framework on students' learning achievements and behaviors in mathematics. Computers and Education, 160, 104031. https://doi.org/10.1016/j.compedu.2020.104031.

Jalili, M., \& Shishavan, H. B. (2020). Responding to student feedback: Individualising teamwork scores $\begin{array}{llll}\text { based on peer assessment. } & \text { ArXiv, }\end{array}$ https://doi.org/10.1016/j.ijedro.2020.100019.

James, S., Lanham, E., Mak-Hau, V., Pan, L., Wilkin, T., \& Wood-Bradley, G. (2018). Identifying items for moderation in a peer assessment framework. Knowledge-Based Systems, 162(January), 211-219. https://doi.org/10.1016/j.knosys.2018.05.032.

Kurniawan, H. R., Elmunsyah, H., \& Muladi, M. (2018). Perbandingan Penerapan Model Pembelajaran Project Based Perbandingan Penerapan Model Pembelajaran Project Based Learning Dan Think Pair Share Berbantuan Modul Ajar Terhadap Kemandirian Dan Hasil Belajar Siswa Kelas XI di SMKN 3 Malang. Jurnal Pendidikan (Teori Dan Praktik), 3(2), 80. https://doi.org/10.26740/jp.v3n2.p80-85.

Liang, H.-Y., Tang, F.-I., Wang, T.-F., \& Yu, S. (2020). Evaluation of Nurse Practitioners' Professional Competence and Comparison of Assessments Using Multiple Methods: Self-Assessment, PeerAssessment, and Supervisor-Assessment. Asian Nursing Research, December, 1-7. https://doi.org/10.1016/j.anr.2020.10.004.

Liu, Q., Huang, J., \& Zhou, Z. (2020). Self-expansion via smartphone and smartphone addiction tendency among adolescents: A moderated mediation model. Children and Youth Services Review, 119(June), 105590. https://doi.org/10.1016/j.childyouth.2020.105590.

Luaces, O., Díez, J., \& Bahamonde, A. (2018). A peer assessment method to provide feedback, consistent grading and reduce students' burden in massive teaching settings. Computers and Education, 126, 283-295. https://doi.org/10.1016/j.compedu.2018.07.016.

M.Ngalim, P. (2007). Psikologi Pendidikan. Remaja Rosdakarya.

Muhammad, A. S. (2018). Peningkatan Keterampilan Fluency Melalui Penerapan Model Pembelajaran Project Based Learning (PjBL) Pada Pembelajaran IPA Di Sekolah Dasar. Jurnal Pendidikan Dasar, 6(1). https://jurnal.fkip.uns.ac.id/index.php/diksar/article/view/11790/8450.

Nilasari, E. P. (2013). Penerapan Model Pembelajaran Kooperatif Tipe Numbered Head Together Untuk Meningkatkan Hasil Belajar IPS Kelas V SDN Sidoarjo. Jurnal Penelitian Pendidikan Guru Sekolah Dasar, 1(2).

Novianti, C., Sadipun, B., \& Balan, J. M. (2020). Pengaruh Motivasi Belajar terhadap Hasil Belajar Matematika Peserta Didik. Science and Phich Education Jurnal, 3(2). https://doi.org/https://doi.org/10.31539/spej.v3i2.992 PENGARUH.

O'Doherty, D., Dromey, M., Lougheed, J., Hannigan, A., Last, J., \& McGrath1, D. (2018). Barriers and solutions to online learning in medical education - an integrative review. BMC Medical Education, 18(130), 1-11. https://doi.org/https://doi.org/10.1186/s12909-018-1240-0.

Oktafia, I. H., \& Wulandari, S. S. (2020). Pembelajaran Daring Sebagai Upaya Study From Home (SFH) Selama Pandemi Covid 19. Jurnal Pendidikan Administrasi Perkantoran, 8(3). https://doi.org/10.1093/fampra/cmy005.

Rahmawati, M., \& Latifah, M. (2020). Penggunaan Gawai, Interaksi Ibu-Anak, Dan Perkembangan SosialEmosional Anak Prasekolah. Jur. Ilm. Kel. \& Kons., 13(1), 75-86. https://doi.org/DOI: http://dx.doi.org/10.24156/jikk.2020.13.1.75.

Rahmazatullaili, R., Zubainur, C. M., \& Munzir, S. (2017). Kemampuan berpikir kreatif dan pemecahan 
masalah siswa melalui penerapan model project based learning. Beta Jurnal Tadris Matematika, 10(2), 166-183. https://doi.org/10.20414/betajtm.v10i2.104.

Samaha, M., \& Hawi, N. S. (2016). Computers in Human Behavior Relationships among smartphone addiction, stress, academic performance, and satisfaction with life. Computers in Human Behavior, 57, 321-325. https://doi.org/10.1016/j.chb.2015.12.045.

Stone, R., Cooper, S., \& Cant, R. (2013). The Value of Peer Learning in Undergraduate Nursing Education: A Systematic Review. ISRN Nursing, 2013(i), 1-10. https://doi.org/10.1155/2013/930901.

Sumarni, I. (2020). Penerapan Model Project Based Learning Untuk Meningkatkan Aktivitas Dan Hasil Belajar Siswa Dalam Mata Pelajaran IPA Tentang Sifat-sifat Cahaya Di Kelas V A Semester II Bagi Siswa SD Negeri Bantarkemang 1 Tahun Ajaran 2017/2018. Jurnal Teknologi Pendidikan, 9(1). https://doi.org/http://dx.doi.org/10.32832/tek.pend.v9i1.2764. 